\title{
Contradicciones culturales de las migraciones en la sociedad globalizada
}

\author{
Juan A. Roche Cárcel \\ Universidad de Alicante. Departamento de Sociología I \\ ja.roche@ua.es
}

\section{Inmaculada Serra}

Univesitat de València. Departament de Sociologia i Antropologia Social inmaculada.serra@uv.es

Recibido: 17-04-2007

Aceptado: 23-07-2007

\section{Resumen}

Los conceptos de «cultura», «migraciones» y "globalización» están relacionados debido a su profunda naturaleza contradictoria, si bien utilizamos aquí la cultura como el factor cohesionador y como una clave importante para hacer el análisis y la interpretación de los fenómenos migratorios. De las múltiples contradicciones que enmarcan a éstos en una sociedad global, vamos a detenernos en cuatro de ellas que consideramos de vital importancia: globalización-localización, individuo-comunidad, identidad-diferencia y espacio-tiempo. Como se comprobará, estas contradicciones generan toda una serie de dilemas que manifiestan tanto los límites y los obstáculos como las posibilidades de solucionar los asuntos migratorios. Además, también se comprobará que, aunque sigue vigente la dimensión espacial, se hace necesario incorporar la dimensión temporal como un factor clave para la comprensión y la articulación de políticas destinadas a los fenómenos migratorios, en tanto que nos encontramos en una sociedad del devenir en la que prevalece el tiempo sobre el espacio. Por eso, estamos obligados a pensar el cambio puro, a tomar conciencia de que ya no es la persecución de la estabilidad y del orden, sino el cambio el que domina las dinámicas sociales y culturales y, entre ellas, las migratorias.

Palabras clave: globalización, sociología de la cultura, cambio social, identidad, espacio, tiempo.

\section{Abstract. The cultural contradictions of migrations in globalized society}

Concepts such as «culture», «migrations», and "globalization» are closely interrelated due to their deep contradictory nature; however, in this work we will use "culture» as an element of cohesion and as an important key in the analysis and interpretation of migratory phenomena. Among the multiple contradictions of these phenomena in the context of a global society, we will point out specially four that we consider as central: globalization/localization, individuals/community, identity/difference, and space/time. As it will be seen throughout this work, the former contradictions engender different kinds of dilemmas that reveal the limits as well as the real possibilities for a solution of migration problems. Moreover, it will also be argued that although space is a crucial factor, it is necessary to incorporate the temporal dimension as a key element to understand and articulate policies targeted towards migratory phenomena, since we face a «flow society» in which time 
prevails over space. That is why we should think of pure change in order to face the fact that change, not stability and order, dominates social and cultural dynamics, and, therefore, migrations.

Key words: globalization, sociology of culture, social change, identity, space, time.

\section{Sumario}
Introducción
4. Espacio-tiempo
1. Globalización y localización
5. Conclusiones
2. Individuo y comunidad
Bibliografía

3. Identidad y diferencia. Nosotros y ellos

\section{Introducción}

Parece obvio que los cinco conceptos - contradicción, cultura, migraciones, sociedad y globalización - que entran en juego en el título de este artículo, al estar colocados juntos, requieren una explicación acerca de su interrelación. En principio, lo que tal vez los unifica de un modo normal sea su propia naturaleza, ya que las contradicciones sociales son inherentes a los procesos de estructuración de la sociedad (Beriain, 1996: 193 s.) y, especialmente, en el capitalismo que se yergue sobre una contradicción intrínseca (Castoriadis, 1979: 106). Además, la cultura posee una naturaleza paradójica (Herkovits, 1987: 29 s.; Berman, 1991: 129 s.) o contradictoria (Weber, 1969: 202; Simmel, 1986: 134), las migraciones están enmarcadas por múltiples contradicciones (Arango, 2003: 21; Abad, 2002) y la globalización nos enfrenta a «profundas contradicciones y paradojas desconcertantes» (Beck, 2006: 1; Beck, 2005, 124 s.). Pero la naturaleza de los fenómenos sociales y, entre ellos, de los migratorios puede tener una explicación más honda y llena de significado, si utilizamos la cultura como una clave importante para su análisis y su interpretación (Aparicio, 1981: 9). Y lo entendemos así, puesto que — como escribe Zygmunt Bauman, En la cultura como praxis (2002, 21-3) — «se puede hablar de la incurable condición paradójica de la cultura», de manera que «la ambivalencia inherente a la idea de cultura [...] es exactamente lo que ha hecho de esa idea una herramienta de percepción y de pensamiento tan fructífera», es decir, una irreemplazable observadora de los fenómenos sociales que se nos muestran contradictorios.

De las múltiples contradicciones que enmarcan las migraciones en una sociedad global, vamos a detenernos aquí en cuatro de ellas que juzgamos de vital importancia. La primera tiene en cuenta que las migraciones están impulsadas o estimuladas por la globalización, si bien sus efectos alcanzan también al plano local. La segunda está relacionada con el modo como tratamos a los inmigrantes, es decir, si los consideramos individuos con derechos y obligaciones o únicamente miembros que debemos integrar o asimilar a una cultura 
común nacional. La tercera se pregunta quiénes son ellos — los inmigrantesy quiénes somos nosotros — la sociedad de acogida - y está, por tanto, vinculada con las nociones de identidad y de diferencia. Y la última contradicción destaca el hecho de que "globalización» y «migraciones» son conceptos espaciales que, sin embargo, hoy están más determinados por el tiempo que por el espacio, categoría ésta que - como se verá-, aunque no desaparece, queda subordinada a aquélla.

Estas cuatro contradicciones serán analizadas aquí buscando los siguientes objetivos:

- Describir los caracteres esenciales que definen a esas contradicciones y su relación con los fenómenos migratorios.

- Revelar hasta qué punto las migraciones son causa o efecto de las contradicciones de la sociedad global.

- Señalar los dilemas más importantes que generan las contradicciones y cómo afectan a los asuntos migratorios. Se trata, especialmente, de profundizar en la ambivalencia que suponen hoy las migraciones, puesto que si bien éstas constituyen un problema o un reto para las sociedades contemporáneas que debe ser resuelto con eficacia y con celeridad, también son una oportunidad de desarrollo económico, político, social y cultural, tanto para los que vienen como para los que acogen.

- Clarificar tanto las posibilidades de encontrar soluciones viables como de señalar los límites y los obstáculos con los que nos encontrarnos a la hora de abordar los asuntos migratorios.

- Llamar la atención sobre la importancia de la dimensión temporal en las migraciones.

\section{Globalización y localización}

Acerca de la noción de globalización y del extenso debate que está produciendo, creemos necesario sintetizar algunos de los aspectos esenciales que definen a este fenómeno en su vinculación con las migraciones.

1. Cabe, ante todo, distinguir entre "globalización», entendida como un fenómeno multidimensional económico, tecnológico, político, social, ecológico, comunicacional y cultural, y "globalismo", relacionado con el neoliberalismo, con la dimensión exclusivamente económica de la globalización y, por tanto, con el sistema capitalista (Giddens, 2003: 23; Beck, 2002: 27-127; Safranski, 2004: 19 s.; García-Canclini, 2001: 29). La globalización ha generado "malestar», porque las instituciones globales (el Fondo Monetario Internacional, el Banco Mundial y la Organización Mundial del Comercio) no han logrado solventar ni los problemas de pobreza, de hambre o desigualdad ni los de estabilidad (Stiglitz, 2003: 30 s.). A ello hay que añadir que no se ha generalizado la idea de globalización, ya que sólo una minoría de políticos, financieros e intelectuales piensan que ésta es «circular» —que afecta a todo 
el mundo-, mientras que la mayoría sólo se la imagina de un modo «tangencial» - para aspectos concretos o particulares, pero no universales- (GarcíaCanclini, 2005: 12). Además, no ha alcanzado a todo el planeta y, más bien, de lo que cabe hablar es de una trilateralización de la economía que conecta a Estados Unidos de América, a Asia y a Europa (Beck, 2002: 166), que son precisamente las zonas donde se encuentran los países receptores de las mayores oleadas de migrantes. Por tanto, el continente africano está quedando fuera de la globalización y tal vez por eso será el próximo emisor más importante de migrantes (Nair, 2006: 34 s.), mientras que la integración de América del Sur en la misma no es total, sino ambivalente, pues en ella conviven contradictoriamente la tradición y la modernidad (García-Canclini, 2001: 81 s.), la emisión de inmigrantes hacia el exterior y las migraciones interiores ${ }^{1}$. En resumen, la ausencia de una globalización total, incluso en el plano económico, está llevando a que se profundicen las diferencias en los procesos de desarrollo económico y social entre continentes, naciones y regiones y, a su vez, a que se incrementen los flujos migratorios internacionales (Abad, 2005: 19)2 . Así es, la globalización o internacionalización de las economías contribuye a la mayor

1. El mapa 1 ilustra que, como consecuencia de la interacción entre las asimetrías económicas y demográficas y las políticas estatales, los migrantes están desigualmente distribuidos en el planeta. En 2005, había 191 millones de migrantes en el mundo: 115 millones en países desarrollados y 75 millones en países en desarrollo (véase el cuadro 1). Por lo tanto, en ese año, el $61 \%$ de los migrantes internacionales vivía en países desarrollados, de los cuales el $34 \%$ lo hacía en Europa; el 23\%, en América del Norte, y el 28\%, en Asia. Finalmente, África sólo tenía el 9\% y, América Latina y el Caribe, el 5\% (véase el cuadro 1).

2. Entre 1990 y 2005, la población mundial de migrantes aumentó en 36 millones, o sea, de 155 a 191 millones, incluidos los refugiados. El ritmo de crecimiento de dicha población se ha ido acelerando. Ha aumentado del 1,4\% registrado durante el período 1990-1995 al $1,9 \%$ correspondiente al período 2000-2004. En los países desarrollados, el número de migrantes aumentó en 33 millones entre 1990 y 2005, mientras que en los países en desarrollo el crecimiento fue sólo de 3 millones. Además, el crecimiento de la población de migrantes se ha concentrado sobre todo en los países de ingresos altos, tanto desarrollados como en desarrollo, puesto que, en 2005 , el $48 \%$ de los migrantes internacionales vivía en países de altos ingresos desarrollados y el $11 \%$ en países de altos ingresos en desarrollo. Ambos grupos de estados registraron un aumento del porcentaje de la población total de migrantes internacionales que acogían en comparación con 1990. Por otra parte, entre 1990 y 2005 , el número de migrantes disminuyó en 72 países, casi todos ellos de ingresos medianos o bajos. Las mayores disminuciones ocurrieron en la República Islámica del Irán y en Pakistán, debido a la repatriación de refugiados de Afganistán. El número de migrantes internacionales también decreció en la Comunidad de Estados Independientes, donde la mayoría de las personas nacidas en el extranjero eran originalmente migrantes internos de la antigua Unión de Repúblicas Socialistas Soviéticas. Aunque los migrantes internacionales se concentran en un número de países relativamente escaso, representan al menos el $20 \%$ de la población en 41 estados, de los cuales 31 tienen menos de 1 millón de habitantes. Hay una alta concentración de migrantes en las naciones miembros del Consejo para la Cooperación en el Golfo y en Hong Kong (China), Israel, Jordania, Singapur y Suiza. Por su parte, en Australia y Arabia Saudita, estados con más de 10 millones de habitantes, los migrantes constituyen por lo menos una quinta parte de la población (Naciones Unidas, 1996, a, b y $c$; Serra, 2000, 2001). 


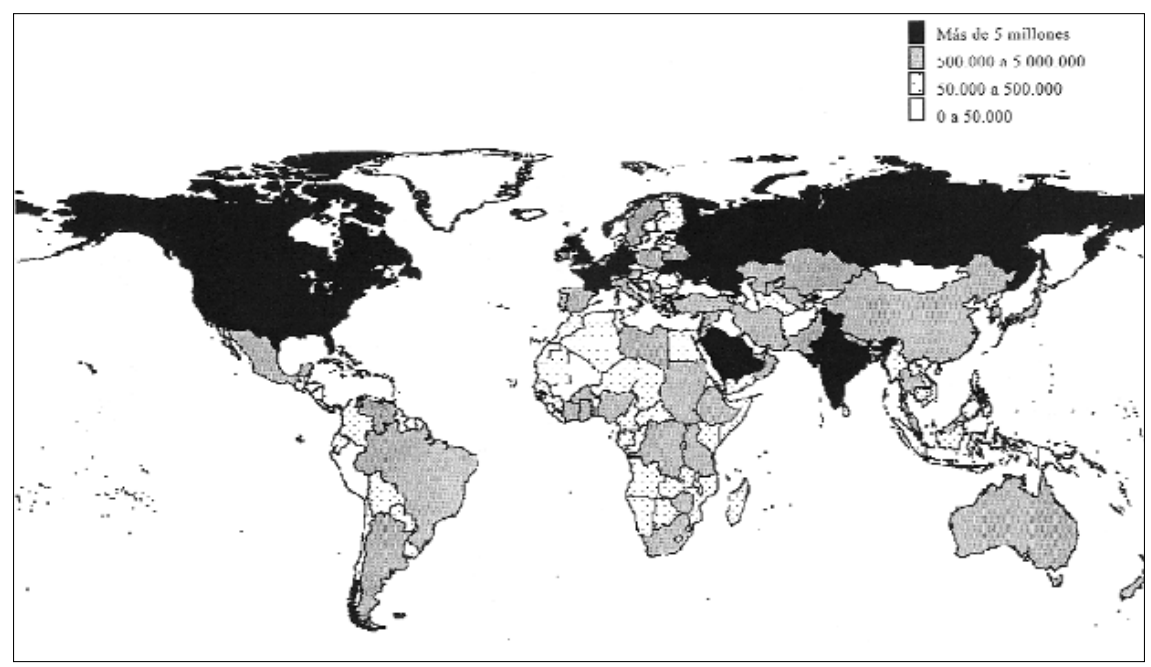

Mapa 1. Número estimado de migrantes internacionales (de ambos sexos) año 2005. Fuente: Naciones Unidas, Trends in Total Migrant Stock: The 2005 Revision.

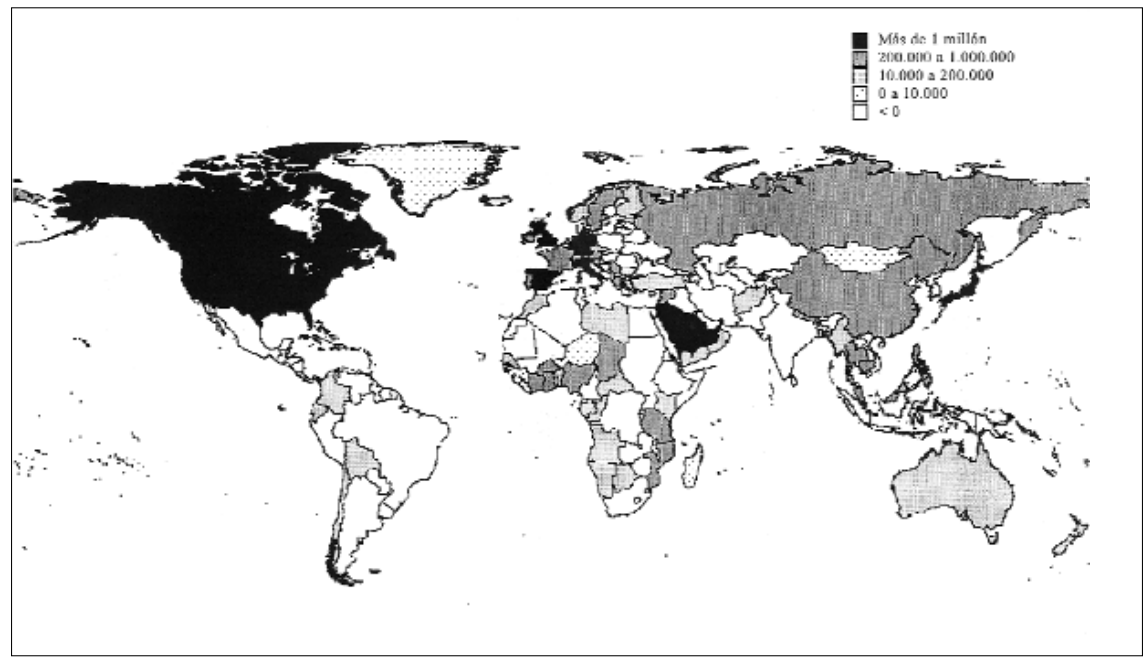

Mapa 2. Cambio en el número de migrantes internacionales: 1990 a 2005 . Fuente: Naciones Unidas, Trends in Total Migrant Stock: The 2005 Revision.

Nota: Los límites que figuran en este mapa no cuentan necesariamente con la aprobación o aceptación oficial de las Naciones Unidas. 
Cuadro 1. Número estimado de migrantes internacionales y su distribución porcentual por zona principal, incluido el porcentaje de mujeres migrantes: 1990-2005

\begin{tabular}{|c|c|c|c|c|c|c|c|}
\hline \multirow[b]{2}{*}{ Zona principal } & \multicolumn{2}{|c|}{$\begin{array}{c}\text { Número } \\
\text { de migrantes } \\
\text { internacionales } \\
\text { (en millones) }\end{array}$} & \multirow{2}{*}{$\begin{array}{c}\begin{array}{c}\text { Incremento } \\
\text { (en millones) }\end{array} \\
1990-2005\end{array}$} & \multicolumn{2}{|c|}{$\begin{array}{c}\text { Distribución } \\
\text { porcentual } \\
\text { de los migrantes } \\
\text { internacionales }\end{array}$} & \multicolumn{2}{|c|}{$\begin{array}{l}\text { Porcentaje } \\
\text { de mujeres } \\
\text { migrantes }\end{array}$} \\
\hline & 1990 & 2005 & & 1990 & 2005 & 1990 & 2005 \\
\hline Mundo & 154,8 & 190,6 & 35,8 & 100 & 100 & 49,0 & 49,6 \\
\hline Regiones más desarrolladas & 82,4 & 115,4 & 33,0 & 53 & 61 & 52,0 & 52,2 \\
\hline Regiones menos desarrolladas & 72,5 & 75,2 & 2,8 & 47 & 39 & 45,7 & 45,5 \\
\hline Países menos adelantados & 11,0 & 10,5 & $-0,5$ & 7 & 5 & 46,2 & 46,5 \\
\hline África & 16,4 & 17,1 & 0,7 & 11 & 9 & 45,9 & 47,4 \\
\hline Asia & 49,8 & 53,3 & 3,5 & 32 & 28 & 45,1 & 44,7 \\
\hline América Latina y el Caribe & 7,0 & 6,6 & $-0,3$ & 5 & 3 & 49,7 & 50,3 \\
\hline América del Norte & 27,6 & 44,5 & 16,9 & 18 & 23 & 51,0 & 50,4 \\
\hline Europa & 49,4 & 64,1 & 14,7 & 32 & 34 & 52,8 & 53,4 \\
\hline Oceanía & 4,8 & 5,0 & 0,3 & 3 & 3 & 49,1 & 51,3 \\
\hline Países de ingresos altos & 71,6 & 112,3 & 40,6 & 46 & 59 & 47,9 & 48,7 \\
\hline Países desarrollados de ingresos altos & 57,4 & 90,8 & 33,4 & 37 & 48 & 50,1 & 50,8 \\
\hline Países en desarrollo de ingresos altos & 14,2 & 21,5 & 7,3 & 9 & 11 & 39,3 & 39,8 \\
\hline Países de ingresos medianos altos & 24,7 & 25,7 & 1,0 & 16 & 13 & 52,5 & 52,9 \\
\hline Países de ingresos medianos bajos & 24,8 & 32,7 & 22,6 & 28,0 & $-2,2$ & $-4,7$ & 16 \\
\hline Países de ingresos bajos & 21 & 12 & 15 & 51,7 & 46,9 & 52,9 & 47,8 \\
\hline
\end{tabular}

Fuente. Naciones Unidas, Trends in Total Migrant Stock: The 2005 Revisión.

Nota: La distribución según el nivel de ingresos se basa en las clasificaciones del Banco Mundial. 
libertad de movimientos y es un estímulo para las migraciones, tanto desde un punto de vista macroeconómico (las migraciones son un producto de la internacionalización del capital) como microeconómico (las migraciones están impulsadas por la información acerca de las diferencias sobre los ingresos, las tasas de paro, los precios y los índices relativos al crecimiento económico). Además, a mayor información y con mejores comunicaciones, se intensifican los intercambios y, con una mayor concentración empresarial, aparecen novedosas desigualdades que, a su vez, generan nuevos motivos para emigrar (González Rabanal, s. a.: 101 s.).

2. Podríamos también caracterizar la globalización como "fronterizada» (Arango, 2003: 10), en la medida en que los estados nación continúan defendiendo ardorosamente sus territorios, es decir, que son entidades políticas cerradas dentro de un sistema mundial abierto (Malgesini, 1998: 33; Portes y otros, 1998: 69). Además, no sólo disminuyen las fronteras, sino que también se construyen nuevos muros artificiales separadores que impiden el paso de las corrientes migratorias, como sucede con la alambrada metálica de Ceuta, la valla de hormigón que aísla Israel de Palestina — que no sólo bloquea el acceso a posibles terroristas, sino también a trabajadores-o el muro que va a ser levantado en el paso entre Estados Unidos de América y México y en la frontera entre Pakistán y Afganistán.

3. Ese malestar y esa fronterización no contradicen el hecho de que la globalización provoca múltiples flujos económico-financieros, tecnológicos, culturales y humanos. Con respecto a éstos últimos, nos interesa destacar aquí algunos aspectos:

- Que, a partir de 1980, las migraciones se producen en un nuevo contexto internacional de carácter contradictorio, puesto que aumentan los flujos comerciales y de capital que se internacionalizan, mientras que las migraciones se mantienen estables (Tapinos, 2000: 50).

- Que los flujos humanos siguen a los internacionales de bienes y de capital, aunque en sentido inverso (Malgesini, 1998: 23).

- Que generan unos movimientos de remesas que causan múltiples efectos sociales, macroeconómicos y políticos, al reducir la pobreza, al ser la principal fuente de financiación internacional de un amplio número de países y, en consecuencia, al ser un motor de desarrollo (Moré, 2005: 98-9).

- Que dibujan un mapa mundial de las migraciones (véanse los mapas 1 y 2) en el que están prácticamente conectados todos los puntos del planeta (Arango, 2003: 9) y en el que se implica a un número cada vez mayor de países emisores o expulsores de inmigrantes que presentan una gran variedad demográfica, social, económica y cultural (López, 2005: 15).

- Que se concentran especialmente en una serie de "fallas tectónicas», de lugares sensibles en los que es mayor la densidad migratoria. Entre ellos, destacan las migraciones Norte-Sur, las del Mediterráneo, las del Golfo 
Pérsico, las de la ribera occidental del Pacífico y las de la frontera norteamericana con México.

4. La globalización afecta a acontecimientos e instituciones, pero también a nuestra vida cotidiana (Giddens, 2003: 16), o sea, a lo que comemos, a lo que vestimos, a lo que respiramos o al modo como diariamente convivimos con los inmigrantes. Y es que la emigración, desde el plano cultural, se vincula con la introducción de nuevos comportamientos, hábitos y pautas de consumo que transforman hondamente las culturas locales y sus estilos de vida (Lacomba, 2005: 159).

5. Hoy sabemos que «globalización» y «localización» son dos fenómenos parejos y profundamente interrelacionados (Isidoro Moreno, 2005: 84) y que las migraciones deben incardinarse en ese doble proceso. $\mathrm{Al}$ respecto, es preciso reflexionar acerca de que los estados se muestran impotentes para controlar los flujos migratorios — como demuestran los casos de las pateras o los cayucos en el Mediterráneo y en el Atlántico canario, el de las migraciones forzadas por el hambre o por la represión que van desde Corea del Norte hacia China y el de los movimientos humanos que se conducen de América del Sur a Estados Unidos de América por la frontera mexicana-. Ello está llevando a que determinados marcos locales —en España, algunas comunidades autónomas (Cataluña, Canarias) y municipios importantes (Madrid, Barcelona); en Canadá (Québec), y, en Estados Unidos de América, ciertos estados como California (Nair, 2006: 92-3; López, 2005: 192)— estén reclamando una creciente intervención en los asuntos migratorios y estén configurando unos espacios de inmigración heterogéneos (Aubarell y otros, 2005: 74). Pero cabe igualmente señalar que «no hay soluciones locales para problemas globales» (Bauman, 2004: 30), es decir, que los entes locales son incapaces por sí mismos de solventar una problemática que claramente les desborda, no sólo por lo que se refiere a la nacionalización de los inmigrantes, sino también en todos aquellos aspectos que requieren acuerdos internacionales o de política exterior y cuantiosas sumas de dinero. El tema de las migraciones, como otros muchos de los que afectan a la sociedad contemporánea - los económicos y los ecológicos, principalmente - indican que nuestro mundo requiere la «glocalización» o intensificación de dependencias recíprocas (Robertson, 1992), esto es, interdependencias y diálogos profundos que vayan desde los entes locales - municipales y autonómicos-, pasando por los estatales hasta las instituciones mundiales y que concilien también los intereses de las cuatro posibles categorías de actores involucrados - poderes públicos, actores cívicos y sociales, empresas y expertos- (Tardif, 2004: 13 s.).

6. Sin embargo, este imperioso diálogo tampoco es un asunto fácil de poner en práctica, puesto que los movimientos migratorios mundiales son anárquicos (Nair y otros, 1999: 32), es decir, que no parece que tengan un control político global, en la medida en que se desarrollan en una globaliza- 
ción sin política, sin sociedad mundial y sin ciudadanía mundial (Beck, 2002: 32 s.). Lo que se requiere, por tanto, es el surgimiento y el arraigo de una política global (Bauman, 2004: 31), un cambio fundamental en la gobernanza para que funcione la globalización (Stiglitz, 2003: 282) y una ética global (Safranski, 2004: 58; Bauman, 2004: 28). Pero esto es sumamente más complicado de lograr en lo que se refiere a las migraciones, puesto que, aunque existen organismos internacionales que velan por los asuntos migratorios - las Naciones Unidas, la Organización Internacional del Trabajo, el Consejo de Europa, la Organización Internacional de las Migraciones y la Organización para la Cooperación Económica y el Desarrollo- (López, 2005: 152), todavía no contamos con una política propiamente global en materia migratoria. Y, por otra parte, tampoco las migraciones están globalizadas en el plano jurídico, ya que éstas han sido excluidas estructuralmente del ámbito de los derechos políticos y, consecuentemente, de la formación del consenso democrático del estado de derecho, y de ahí que se encuentren fuera de la democracia y del reconocimiento político (Nair y otros, 1999: 167).

\section{Individuo y comunidad}

Al menos desde el siglo XVIII, en el mundo occidental, existen dos modelos contrapuestos entre lo individual y lo social (Iglesias, 1999: 223 s.): el defendido por Montesquieu, y que heredará el liberalismo kantiano, mantiene que el individuo se sitúa por encima del estado, mientras que el sostenido por Rousseau y por Herder, Fichte y Hegel (quien reclama un estado absoluto) considera que la voluntad común —el pueblo, la nación, el estado- debe hallarse por delante de la del individuo. Estos dos modelos antagónicos se han expresado, en la historia reciente de Occidente, respectivamente, en el modelo socialista y proletario, que contempla el progreso a través de la acción colectiva de la clase obrera, y el liberal e individualista, que se centra en el empuje del individuo (Tapinos, 2000: 48).

Pero esta tensión entre lo individual y lo comunitario va más allá de lo meramente político, pues posee un amplio alcance cultural y social. Cultural, en la medida en que se manifiesta en la propia naturaleza paradójica de la cultura, ya que ésta es, al mismo tiempo, "capacitadora», «autoafirmativa» y "restrictiva» $\mathrm{O}$ "reguladora y normativa», es decir, individualista y/o societaria (Bauman, 2002: 19-20). Por eso, la identidad cultural posee «dos bestias negras: el individualismo y el cosmopolitismo» (Finkielkraut, 2000: 79), que están presentes en el profundo debate producido dentro del multiculturalismo acerca de si sólo deben reconocerse los derechos individuales o también los colectivos de los pueblos, de las naciones, de las etnias y de las culturas. Habermas y Taylor representan los dos puntos de vista del debate: la posición liberal, decantada por el primero, insiste en principios morales universales y en que el individuo trasciende todo grupo cultural, y la multiculturalista, propugnada por el segundo, que cree en la necesidad de otorgar derechos a los grupos colectivos y no sólo a los individuos (Velasco, 2001: 129-30; Morán, 2001: 160 s.). En España, 
la reciente contienda sobre el Estatuto catalán, las sucesivas reclamaciones de los nacionalismos periféricos y las reacciones ante éstas de los nacionalismos centralistas manifiestan también que el conflicto entre lo individual y lo colectivo está lejos de resolverse. En cuanto a Francia, tal vez el fracaso de su modelo migratorio asimilador, basado en el ideal republicano del estado nación, se deba a su escasa atención al individualismo, a los problemas concretos de cada uno de los inmigrantes (Nair, 2006: 106).

El alcance sociológico de la contraposición entre lo individual y lo societario se observa en el deseo de la sociología de conciliar lo individual y lo social, «las inquietudes personales del medio» y «los problemas públicos de la estructura social», lo que constituye una de las esencias de la imaginación sociológica (Wright Mills, 1999: 27), y en la propia historia de la disciplina que ha basculado entre darle preeminencia a lo colectivo frente a lo individual —Durkheim y la escuela francesa - o, por el contrario, a conceder un papel relevante a los individuos - Weber y la sociología clásica alemana- (González García, 1992: 31-3). Además, este antagonismo se evidencia igualmente en los aspectos más determinantes de la crisis de la sociedad contemporánea y en los modelos públicos de integración social de los inmigrantes. La actual crisis social se pone de manifiesto en varios asuntos importantes:

a) En el cuestionamiento del estado nación por arriba y por abajo (Sartori, 2003: 45; Mardones, 2001: 40). Por arriba, presionado por los efectos de la globalización que desnacionaliza (Beck, 2002: 34), por el poder de las instituciones mundiales y de un capitalismo mundializado que deslocaliza el capital y el trabajo y por la absorción de competencias tradicionales de los estados nación por organismos supranacionales - la Unión Europea, por ejemploY, por abajo, por las reclamaciones de mayores cotas de autogobierno por parte de las naciones que forman parte de esos estados. En este sentido, creemos que se ha anunciado demasiado prematuramente la muerte del estado nación (Giddens, 2003: 21; Beck, 2002: 42), pues lo que observamos es una lucha del mismo por adaptarse a las nuevas condiciones sociales. Su posible victoria o derrota sólo el tiempo la aclarará, pero, en cualquier caso, nuestra posición cuenta en estos momentos, al menos, con cuatro poderosos argumentos. El primero, parte de la siguiente pregunta: ¿quién puede negar la fortaleza de estados como el norteamericano, el chino, el ruso, el francés, el alemán o el británico? El segundo incide en que, posiblemente, estemos asistiendo a una transformación de los estados nación absolutos de corte hegeliano a otros - como en el caso español o en el europeo- que avanzan hacia un estado plurinacional. Y el tercer argumento se centra, sobre todo, en el caso del Estado norteamericano, de vieja raigambre liberal debido a que ese antiguo liberalismo está evolucionando hacia nuevas cotas que dibujan un estado ambivalente, muy fuerte y poderoso en el exterior — sobre todo como potencia política, económica, cultural y armamentística-, pero, al mismo tiempo, débil en el interior, pues se muestra incapaz de resolver con eficacia catástrofes naturales como la del huracán Katrina que asoló Nueva Orleans o de diseñar políti- 
cas económicas o sociales, debido tanto a las competencias de los estados federados como a las presiones de poderosos lobbys o grupos sociales - el de los pensionistas, por ejemplo- (Jay y otros, 2000: 208 s.). El cuarto y último argumento destaca la importancia que el estado ha tenido siempre y sigue teniendo en el tema de las migraciones, al menos en los siguientes asuntos: en políticas de regulación y control de flujos, en el impacto de la inmigración en la política exterior de los estados, en el efecto de la inmigración en el sistema político o en la política de los países receptores, en la integración de los inmigrantes (en los derechos económicos y sociales), en el transnacionalismo (López, 2005: 25 s.) y en el hecho de que es la única institución que puede garantizar la igualdad del inmigrante con el resto de la población de un país otorgándole la ciudadanía (Malgesini, 1998: 33).

b) En la crisis de la ciudadanía. Actualmente, en las sociedades occidentales, al parecer, predomina un individuo descomprometido y ajeno a los asuntos públicos en guerra contra el ciudadano que es el que se interesaba por el bien común (Bauman, 2003: 35 s.). Además, la entrada masiva de inmigrantes, al no obtener los mismos derechos que los ciudadanos de los países de acogida, ha encogido el concepto de ciudadanía, situándolo a la baja o creando en ella una escala jerárquica de gradaciones que sitúa en primer lugar a los nacionales; en segundo, a los naturalizados; en tercero, a los denizens o residentes indefinidos; en cuarto, a los temporales, y, finalmente, a los irregulares (Arango, 2003: 19). Si a ello le añadimos que estas corrientes han enfrentado al viejo orden del derecho internacional —-basado en la mirada nacional y apoyado en los principios de la colectividad, de la territorialidad y de las fronteras- con el nuevo orden del derecho humano - fundado en la mirada cosmopolita y en el individuo como titular de los derechos humanos subjetivos- (Beck, 2005: 169), se entenderá entonces que las migraciones hayan cuestionado profundamente la visión que vinculaba la ciudadanía al estado nación (Ugur, 1998: 329), porque la ha contrapuesto a los derechos del hombre, que son universales (Nair y otros, 1999: 91). Y ello nos obliga, en definitiva, a desarrollar un nuevo tipo de ciudadanía que concilie lo local (el oikos) y lo global (el ágora).

c) El desvanecimiento o muerte del sujeto (Thiebaut, 1996: 228; Jameson, 1998: 228), porque ahora éste es un individuo subsumido en una masa triunfante (Baudrillard, 1978: 7), consumista y hedonista (Bell, 1992: 11 s.), pervertido por las costumbres de la cultura del dinero (Dewey, 2003: 60), en definitiva, es un individuo consumidor y no productor (Bauman, 2003: 178 s.).

Todos estos aspectos de la crisis social actual afectan al modo como tratamos a los inmigrantes, es decir, si son considerados como sujetos individuales provistos de derechos y obligaciones o como ciudadanos, miembros de un estado o nación en el que hay que integrarlos. En este sentido, cabe igualmente señalar que la globalización está extremando esta tensión entre los intereses de 
los individuos y los de las sociedades organizadas en estados (López, 2005: 17). Todo ello se aprecia en los cuatro modelos migratorios más importantes que, hasta ahora, han generado los estados para integrar a los inmigrantes en sus sociedades (López, 2005: 77 s.; Luisa Moreno, 2005: 137 s.):

1. El «exclusivo», basado en el carácter étnico e identitario colectivo y puesto en vigor por Alemania y Japón. Se caracteriza por no reconocer la ciudadanía a los inmigrantes, puesto que ésta se vincula al ius sanguinis (al derecho de sangre) y no al ius solis (al derecho de suelo). Es cierto, sin embargo, que la permanencia durante décadas de importantes minorías de inmigrantes sin que hayan sido nacionalizados - como la de los turcos en Alemania- han llevado a que este rígido modelo haya sido suavizado, sobretodo desde 1993 y 1999, mediante una serie de sucesivas legislaciones que han estipulado compaginar ambos derechos - el de sangre y el de suelo_- para la obtención de la ciudadanía. Por otro lado y al menos en el caso de Alemania, la imposibilidad o dificultad de integrar definitivamente a los inmigrantes ha sido compensada con políticas sociales avanzadas que cubrían muchas de sus necesidades.

2. El «asimilador», puesto en práctica por Francia, basado en el laicismo y la noción republicana del estado nación y que privilegia el carácter colectivo frente al individual. Su característica esencial es la integración de los inmigrantes como ciudadanos de la República, en tanto que acepten las leyes laicas, la igualdad de los ciudadanos ante la ley y la lengua francesa. En definitiva, siempre que se asimilen culturalmente al país de acogida, sin que su cultura de origen sea considerada o valorada. Este modelo, en líneas generales, tuvo éxito aproximadamente hasta 1970, pero desde entonces ha entrado en crisis, de modo que hoy podemos juzgarlo ambivalentemente, dados sus éxitos y fracasos parciales en la integración de los inmigrantes. El triunfo, por ejemplo, se constata en la consideración unánime de la jerarquía islámica como francesa ante el secuestro de un periodista francés en Irak o ante la legislación republicana de prohibir el velo islámico en las escuelas. Por el contrario, el fracaso ha saltado a la opinión pública tras los dramáticos y recientes incidentes en los barrios marginales de París y de otras ciudades protagonizados por poblaciones de origen inmigrante que protestan por la marginación y por la exclusión de la que hoy son objeto, a pesar de sentirse como franceses. Igualmente, el naufragio de ese modelo asimilador se hace patente en la subordinación de la mujer en esos mismos barrios.

3. El «multicultural», basado en una concepción liberal en la que prevalece el factor individual frente al colectivo. Implantado especialmente por los países anglosajones -Estados Unidos de América, Gran Bretaña, Australia, Nueva Zelanda y Canadá - y también por estados como Suecia u Holanda, se define por no requerir la asimilación de los inmigrantes y sus culturas. Es un modelo que está siendo cuestionado en estos momentos al menos por tres acontecimientos: los atentados de Londres del 7 de julio del 2005, perpetrados por 
británicos de origen inmigrante y confesión islámica; el asesinato del cineasta Theo Van Gogh cometido en Holanda por un ciudadano holandés de procedencia marroquí, y la reclamación, por parte de los inmigrantes musulmanes, de la aplicación en Canadá de la Sharía o ley islámica. Si a esto le añadimos que en USA sólo los intelectuales parecen decantarse por este modelo y que no cuenta con un sistema desarrollado de derechos sociales (Nair, 2006: 91 s.), se entenderá que se encuentre en una profunda crisis.

4. El «intercultural», que todavía no ha sido puesto en práctica por ningún estado, si bien es defendido por un número cada vez mayor de intelectuales (García-Canclini, 2001: 20; Giovanni Sartori, 2003; Maalouf, 2004) y que se utiliza cada vez más en asuntos específicos como la educación. Es un modelo basado en dos conceptos: reciprocidad e interrelación o diálogo (Sartori, 2003: 33-6; Maalouf, 2004: 50). En cuanto a la noción de reciprocidad, ésta se refiere a la obligación de respetar los derechos culturales de los inmigrantes por parte de la sociedad receptora, pero, al mismo tiempo, se exige a los inmigrantes que acepten nuestras leyes, así como la sociedad que los ha acogido y los derechos humanos que ésta impulsa. Así, por ejemplo, no es posible, desde la interculturalidad, defender la ablación de las niñas africanas, como tampoco sería entendible aceptar los matrimonios de las mujeres pakistaníes obligadas por sus padres a casarse por contrato en Pakistán. Y, por lo que se refiere al concepto de interrelación o diálogo, la interculturalidad defiende que las culturas del origen enriquecen a las de destino y que, por tanto, debe establecerse un proceso de diálogo fructífero entre ambas. Por todo ello, es un modelo situado a mitad de camino entre el asimilador, que niega la cultura de origen, y el multiculturalista, que otorga a ésta un valor absoluto. En consecuencia, exige la necesidad de un recíproco respeto mutuo y de un profundo diálogo entre ambas para construir una cultura y un código normativo común (Nair y otros, 1999: 197). Sin embargo, debe tenerse en cuenta que, en todo diálogo cultural, siempre existe una jerarquización que, en nuestra opinión, debe ser contrarrestada, tanto por una regulación ética que escuche con una especial atención a la cultura subordinada, como por la evitación de la caída en el victimismo a la que suele recurrir este último tipo de cultura.

\section{Identidad y diferencia. Nosotros y ellos}

Hoy, el sentido de los otros «se pierde y se exacerba a la vez», lo que está relacionado con una crisis de la identidad que produce procesos generadores de alteridad (Augé, 1996: 11 s.) e, incluso, de «identidades asesinas» (Maalouf, 2004).

Con respecto al «nosotros», caben seis aspectos identificadores:

a) Las sociedades antiguas poseían una identidad cerrada y limitada, de manera que lo de dentro era considerado la identidad, mientras que lo de fuera era visto como el espacio de «los bárbaros», de «los metecos» (el nombre que reci- 
bían en la Grecia antigua los comerciantes extranjeros) o de "los bastardos» (en la Biblia, los hijos ismaelitas de Abraham). Hasta la edad media persiste este tipo de identidad, lo que se ejemplifica muy bien en los claustros, en la sociedad autárquica feudal o en las ciudades amuralladas. El Renacimiento supone el fin de la identidad cerrada y la apertura hacia una de cuño infinito, abstracto y sólo delimitada por la voluntad del hombre, es decir, por la razón. Pero, en realidad, el «otro» debía transformarse a imagen y semejanza del europeo si no quería ser visto como un extraño o como un extranjero (como sucedió, por ejemplo, con los indios americanos). Por tanto, este modelo de identidad no termina siendo abierto, sino expansivo, pues se ha pasado de la identidad cerrada y limitada del mundo antiguo a la identidad exteriorizante, expandida y sin fronteras de la nueva etapa (Coppens, 2002: 47-84).

b) Tras la crisis religiosa expresada en la Reforma, en la Guerra de los Cien Años y en el conflicto ilustrado entre razón y fe y tras los descubrimientos científicos que conducen a la pérdida de la centralidad de la Tierra (Copérnico) y al progresivo alejamiento del hombre de la naturaleza física, el individuo moderno siente que se desintegra, que debe cuestionar su identidad y su unidad y que ya no puede apoyarse ni en la religión ni en el mundo exterior, sino en sí mismo (Roche, 2005: 15).

c) Este yo en el que el individuo moderno busca apoyo se encuentra escindido y en conflicto con el exterior, con el mundo, y con su interior, con el que libra una auténtica guerra civil (Kant, 2003: 591; Hegel, 2000: 229; Freud, 1995: 20 s.).

d) Hoy la identidad "parece exigir que se la piense contra el tiempo» (Rodríguez, 2007, 153), ya que el tiempo la ha moldeado transformando su naturaleza. En efecto, la identidad es actualmente aleatoria (Nair y otros, 1999: 77 s.), proteica e inestable, y ha sido precisamente el nuevo capitalismo, con su flexibilización de la organización del trabajo, el que ha conllevado esta variación, puesto que ha hecho que la experiencia valga poco y que el yo sea maleable y «un collage de fragmentos que no cesa de devenir, siempre abierto a nuevas experiencias» (Sennet, 2000: 140). Por eso, los humanos no nacemos ya en una identidad dada, sino que la construimos, y ésta se conforma más como un proyecto inacabado que como algo fijo e inmutable (Fullat, 2002: 28 s.; Bauman, 2003: 88 s.) y se transforma, por tanto, de algo «dado», en una "tarea», en un "proyecto". Y esto quiere decir que la identidad ya no se nos da de una vez por todas, sino que se va construyendo y transformando a lo largo de toda nuestra existencia, lo que trae aparejadas hondas consecuencias. La primera, que la mutabilidad es un signo de la identidad (Coppens, 2002: 12), puesto que se puede ser primero heterosexual y, más tarde, homosexual, se puede sustituir la ideología política a lo largo de la vida, se cambia de profesión en diversas ocasiones, se contrae matrimonio varias veces y se renueva incesantemente de ropa con arreglo a las modas. La segunda, que ahora la mayor parte de 
las identidades colectivas «son más bien camisas que piel», esto es, son opcionales y no ineludibles (García-Canclini, 2004: 36). Y la tercera consecuencia, que «el tiempo no es el enemigo de la identidad, sino que es, al revés, su condición» (Rodríguez, 2007, 153).

e) Las identidades son también más plurales que únicas, puesto que todos los seres humanos sin excepción poseemos una identidad compuesta, compleja y con pertenencias múltiples, con lo cual conformamos una identidad que, aunque se percibe como única e irreemplazable, no está hecha de compartimentos, no se divide en mitades ni en zonas estancas. Es, por tanto, una identidad única producto de todos los elementos que la han configurado mediante una dosificación y una selección. Es verdad, sin embargo, que en ocasiones estas pertenencias múltiples se oponen entre sí y nos obligan a elegir, lo cual produce un desgarro o, en los casos más extremos, una reducción de la identidad compleja a una sola cosa que conlleva sectarismo, intolerancia o «identidades asesinas» (Maalouf, 2004: 10).

f) La identidad es consumida y no producida, en la medida en que su búsqueda constituye una lucha continua por detener el flujo, por dar forma a lo informe, lo que se consigue comprando la identidad individual mediante el consumo conspicuo (Bauman, 2003: 82 s.).

Y en relación con «ellos», con los inmigrantes que se desplazan, pensamos que puede sernos útil el concepto de «cultura profunda» empleado por el sociólogo Johan Galtung (1995), que sostiene que esta noción permite definir en lo más hondo los fenómenos sociales y, en este caso, la identidad de los inmigrantes. Por lo que se refiere a España, los inmigrantes proceden principalmente de Suramérica (Bolivia, Argentina, Colombia, Perú, Brasil, Ecuador), de los países del Este europeo (Rumanía, Bulgaria, Polonia, Rusia), del Magreb - Marruecos y Argelia-, del interior de África y de China (Izquierdo y otros, 2007: 8 s.). En entrevistas y conversaciones con los inmigrantes de origen suramericano ${ }^{3}$ se desprende que lo que echan de menos de su tierra no son sus ciudades o sus sociedades sino las maravillas naturales que han dejado atrás, de las que sienten una profunda nostalgia. Esto es lógico si se tiene en cuenta que su polis está realmente descompuesta por los altos niveles de corrupción política, por la debilidad de las democracias o por la instauración de regímenes totalitarios o populistas y por las profundas desigualdades sociales y los altos niveles de pobreza. Así pues, manifiestan un malestar social y una nostalgia de la naturaleza. Para nosotros esto desvela que, en realidad, ellos sienten que han sido expulsados del Paraíso hacia una tierra de trabajo, de sudor y de sufrimiento, hacia un valle de lágrimas.

3. Estas entrevistas han sido desarrolladas dentro del proyecto de investigación de I+D. Entre la Soledad y el Coraje. Cultura, mujer e inmigración en la Comunidad Valenciana, dirigido por Juan A. Roche Cárcel y apoyado por la Generalitat Valenciana. 
Los marroquíes o argelinos, por su parte, no dejan de considerar que la tierra de acogida hacia la que emigran se encuentra hacia el oeste, hacia el lado contrario donde dirigen sus rezos, en donde se halla la tierra santa (Jerusalén o La Meca). Por tanto, en el fondo mítico de su corazón interpretan que la tierra de acogida es una tierra impía.

Los europeos del Este vienen hacia el Occidente, que, hasta 1989, representó «lo prohibido» y que, ahora, es concebido como lo «necesario». Toda vez que estos países del antiguo ámbito comunista habían secularizado el mito, el combate de los inmigrantes más bien parece adoptar términos freudianos, pues en ellos batallan los planos consciente e inconsciente, el principio del placer con el principio de la realidad, lo prohibido y lo necesario.

Finalmente, los africanos que se están jugando la vida en esos cayucos que llegan a las costas canarias han tenido que realizar un largo viaje y atravesar el desierto, un espacio de la nada, de la ausencia y de la muerte, tras el que esperan alcanzar la gloria de la vida y solventar, así, sus múltiples desgracias. Basta contemplar la cara de desconcierto profundo de estos inmigrantes al ser expulsados para constatar que lo que les turba es que lo que encuentran más allá del desierto no es precisamente — como lo era en su tierra — la vida cósmica que les conectaba panteísticamente con el mundo, con el universo entero, sino, por el contrario, lo que los margina, los fractura y los desgarra violentamente del mismo.

Vistas así las cosas, en una sociedad occidental formada por individuos cuyo yo se encuentra escindido del mundo y en batalla consigo mismo y cuya identidad está formada por pertenencias múltiples y caracterizada por ser un proyecto temporal, aleatorio, mudable, proteico e inestable y más consumido que producido, ¿es posible el diálogo con gentes que sienten que han sido expulsadas del paraíso hacia un valle de lágrimas, con personas que creen que están en una tierra impía, con individuos que luchan incesantemente entre el placer y la realidad, entre lo prohibido y lo necesario y con lejanos expatriados violentamente desgarrados del mundo?, ¿es viable un diálogo sincero, profundo y constructivo entre nosotros y ellos, entre las sociedades de acogida y los inmigrantes, entre la identidad y la diferencia?, ¿es permisible construir nuevas identidades que no borren la cultura de partida o que no olviden las culturas de origen?

La tarea es necesaria y urgente y se ve claramente en la evolución de la actividad del estado en relación con las migraciones. En esa materia, podríamos decir que la política de los estados ha pasado de primar los factores demográficos y económicos a fijarse en otros, como la identidad nacional y la unidad cultural (López, 2005: 25 s.). En este sentido, es preciso no olvidar que el Otro es siempre la proyección, el rechazo o la negación de una parte del Yo, esto es, que «el Otro es el Yo más la representación de la diferencia entre ambos» (Sami Nair y otros, 1999: 125) y que, por tanto, la identidad está relacionada con la alteridad, que es su complemento (Sartori, 2003: 48) y con la relación que se establece con ella, de manera que la personalidad del individuo se conforma entre el ser y la relación (Augé, 1996: 24)). Si lo que se pretende es la total integración de los inmigrantes, esto sólo se lograría con el paso de la alteridad a la identidad (Malgesini, 1998: 28). Pero la realidad es tozuda, ya que, según 
Claude Lévi-Strauss (Tristes tópicos, 1988), a lo largo de la historia humana y todavía hoy se dan, fundamentalmente, dos estrategias para enfrentar la «otredad», dos maneras que no están basadas precisamente en el diálogo con lo otro, sino en su eliminación:

1. «Vomitar», expulsar a los otros, lo que se hacía, antiguamente, prohibiendo todo contacto físico (por ejemplo, en los guetos judíos de la Europa medieval) $\mathrm{y}$, actualmente, en los guetos urbanos que mantienen aislados y marginados en los barrios periféricos de las ciudades a poblaciones de razas, etnias, religiones o culturas diferentes a las del resto de ciudadanos de la nación o del estado.

2. «Devorar» cuerpos y espíritus extraños para convertirlos, por medio del metabolismo, en cuerpos y espíritus «idénticos», no diferentes al cuerpo que los ingirió.

La primera estrategia tiende al exilio o a la aniquilación de los otros, mientras que la segunda pretende la desaparición de la otredad.

\section{Espacio-tiempo}

Cuando pensamos en la globalización y en las migraciones, normalmente creemos que son únicamente conceptos espaciales, como sucedía en la antigüedad, cuando las migraciones estaban motivadas fundamentalmente por las transformaciones climáticas y geográficas de la Tierra o por la búsqueda de nuevas zonas de caza, de cultivo y de pastos. Y aunque la globalización y las migraciones siguen desarrollándose en el espacio, sin embargo, hoy tenemos que pensar que la dimensión temporal ha entrado a formar parte de ellas de una manera determinante. Y ello debido a tres causas. En primer lugar, porque mientras que para Kant las categorías de espacio y tiempo son sintéticas a priori, esto es, constituyen las categorías fijas de la mente que permiten organizar la experiencia, para el historicismo de Wilhem Dilthey (Bell, 1992: 114) y para el relativismo de Albert Einstein (Russell, 1984: 116) ni el espacio ni el tiempo son fijos, sino que cambian, respectivamente, según los modos culturales o la perspectiva subjetiva, lo cual evidencia los fallos de la teoría de la gravitación de Newton (Bronowski, 1978: 74-5). En segundo lugar, frente a los pueblos antiguos que aspiraban a ser (Eliade, 1952: $22 \mathrm{~s}$.), en la sociedad moderna ha triunfado el devenir (Hegel, 2000: 12 s.; Darwin, 1985: 79 s.; Darwin, 1986: 9 s.; Marx, 1985: 37 s.; Marx, 1987: 42; Baumer, 1985: 379 s.; Roche, 2004: 978). Y, finalmente, en tercer lugar, en contraste con la antigüedad, en la que dominaba el espacio sobre el tiempo — como sucede, por ejemplo, en $\mathrm{La}$ Divina Comedia, de Dante ${ }^{4}$, que «traza un mapa del tiempo dentro del espa-

4. La Divina Comedia de Dante, al empezar con estas palabras, «En mitad del camino de la vida me hallé en el medio de una selva oscura después de dar mi senda por perdida» (Dante, 1995: v. 1-4), utiliza metáforas espaciales para señalar la edad (35 años) del protagonista. 
cio» (Steiner, 2001: 86)—, en la modernidad el tiempo prevalece, comprime, reduce o aniquila el espacio (Kant, 2003: 77 s.; Smith, 2007: 534; Simmel, 1977; Benjamin, 1973; Baudelaire, 2004: 91-2; Harvey, 1998: 268; Giddens, 2003; Bauman, 2003: 120; Bauman, 2006: 12)5.

Estas tres causas han traído aparejadas profundas consecuencias existenciales y sociales, institucionales e individuales, para las sociedades receptoras y para las inmigrantes, tanto en lo que se refiere a la manera de entender el tiempo como a la de concebir el espacio. Por lo que se refiere a la primera, destacan las siguientes implicaciones:

a) El triunfo del tiempo ha conducido a que la economía capitalista de mercado solucione sus problemas de producción y de distribución de una manera dinámica y no estática, como ocurría en la economía tradicional (Heilbroner y Milberg, 1999: 46 s. y 154). Además, actualmente ésta está marcada por la flexibilidad, la ligereza, la fluidez, el desarraigo, el azar, el caos, la inestabilidad, el nomadismo y la movilidad ${ }^{6}$. Así es, el nuevo espíritu del capitalismo, mediante una estrategia de escape, de evasión y de retirada, ha transformado la solidez en liviandad y el territorio, en flujo, y lo ha hecho con la voluntad de ganar ligereza para desplazarse más deprisa. Y esto se observa tanto en la elite empresarial, en el capitalismo, en el trabajo y en la visión del poder, que han sido modificados por el impulso del devenir. Va a quedar atrás la época de la superioridad de la elite sedentaria (el fordismo) sobre el nomadismo, pues ésta va a ser sustituida por otra más nómada y extraterritorial — gracias a las redes electrónicas - que desconfía de toda estructura, que rechaza lo durable y que celebra lo efímero. Esta elite empresarial ha conformado, además, un capitalismo liviano que cambia aceleradamente de productos industriales que son inestables y precarios, de modo que la lógica económica ha eliminado todo ideal de per-

5. El sociólogo Manuel Castells cree que hoy en la sociedad red el espacio es el que domina sobre el tiempo y que éste es atemporal; de hecho, utiliza la metáfora espacial de "sociedad red", más propia de otro tiempo. Véase el número 86, de 1999, de la REIS, en el que aparece un artículo suyo y, especialmente, el fino trabajo de Ramón Ramos Torre, «Red, identidad, espacio y tiempo», p. 86-99. Sin embargo, desde nuestra perspectiva, en la antigüedad el tiempo domina sobre el espacio por dos motivos: el primero, porque, en la antigüedad - como ya he indicado-, prevalecía el espacio sobre el tiempo y no creemos que nuestra situación sea comparable tras la irrupción de las nuevas tecnologías de la comunicación, de la información y del transporte y tras las consecuentes profundas transformaciones económicas, sociales y culturales; el segundo, porque el dominio del tiempo sobre el espacio constituye una tendencia de larga duración, pues al menos desde el siglo XVIII — desde Kantmultitud de autores y todos ellos de una gran importancia - puede verse la lista que señalo en el apartado 4 de este artículo dedicado al espacio y al tiempo- han analizado ese dominio.

6. Las características espacio-temporales del nuevo capitalismo las hemos elaborado mediante las siguientes lecturas: Luc BOLTANSKI y Eve CHAPIELLO, El nuevo espiritu del capitalismo, especialmente las p 146 y s.; Robert HeILBRONER y William MilberG, La evolución de la sociedad económica, p. 8 y s. y p. 46 y s. y 154; J. RIFKIN, La era del acceso, p. 14 y s.; Guy DEBORD, La sociedad del espectáculo, p. 132-3; Celso SÁNCHEZ CAPDEQUí, Las máscaras del dinero, p. 300, y Richard SENNETT, La cultura del nuevo capitalismo, p. 42. 
manencia, siendo la norma de lo efímero la que preside la producción y el consumo de los objetos. Bill Gates es un ejemplo de ello, pues se separa de sus posesiones sin ningún aprecio a las mismas, considera que lo que hoy reporta beneficios es la velocidad de circulación, el reciclado, el reemplazo y no la durabilidad del producto, y crea artículos que aparecen y desaparecen a una gran velocidad. El dominio del devenir también se advierte en la obsesión del capitalismo liviano por reducir e, inseparablemente, por fusionar. Y es que la combinación de las estrategias de fusión y de reducción permite, al capital y al poder financiero, un espacio y un tiempo en el que moverse rápidamente, globalizando todavía más el mundo - como normalmente hacen con sus viajes de negocios, con sus ventas y con sus sucursales - y unificando mundialmente el tiempo irreversible, el tiempo de la producción, el tiempo mercancía, que es una acumulación infinita de instantes equivalentes y, por tanto, la abstracción del tiempo irreversible. Esta pérdida de la permanencia se percibe igualmente en el despojamiento del poder de negociación y rebelión del trabajo, puesto que se sustituyen los compromisos duraderos por acuerdos a corto plazo y por encuentros fugaces, de modo que han quedado debilitados los lazos entre el capital y el trabajo y éste se ha vuelto menos sólido y más frágil e incierto que nunca. Además, el trabajo se ha convertido —al igual que los objetos materiales - en una fuerza menor frente a las ideas o los conceptos y se ha flexibilizado hasta tal punto que una persona puede cambiar una media de once veces de puesto de trabajo en su vida laboral — como sucede, por ejemplo, en USA$y$, por otra parte, si busca empleo, se encuentra con que, de cada diez nuevos puestos, nueve son estrictamente temporales y a corto plazo. En definitiva, este sistema económico ha generado una nueva manera de concebir la economía que fluye más libremente y es menos duradera y más instantánea. En este fluido contexto económico se desarrollan las migraciones, que están determinadas más por el movimiento que por el asentamiento (Sennet, 2006: 10), especialmente en el transnacionalismo, que se caracteriza por el fin de la circularidad — del asentamiento- y por su sustitución por una dimensión temporal basada en la periodicidad, en la duración discontinua de las estancias y, en definitiva, en la movilidad (Mendoza, 2004). Y a esto hay que añadir que las migraciones se han acelerado (López, 2005: 16) ${ }^{7}$, que muestran una con-

7. Un caso significativo de la aceleración de las migraciones lo representa España (Navarro, s. a.). En efecto, la transición de España como país de emigración hasta convertirse en un receptor de inmigrantes se ha cubierto en menos de diez años, en la medida en que el núcleo de tal transformación hay que situarlo entre 1985 y 1994. El Informe FOESSA, publicado en el año 1995, señalaba que «de trece millones de inmigrantes que residen en la Unión Europea, en España habría unos 700.000 que, con los ilegales, podrían aproximarse a los 800.000 , lo que supone un $2 \%$ de nuestra población. Pero si la mitad de dicho porcentaje proviene del Primer Mundo, podemos concluir que los inmigrantes no comunitarios serían el 1\% de la población total» (V Informe FOESSA, 1995: 207-209). Esta rápida transformación se ha acelerado todavía más recientemente, puesto que, según el Instituto Nacional de Estadística (INE, 2006) —son los últimos datos disponibles en el momento de redactar este artículo que corresponden al 1 de enero del 2005, hechos públicos el 17 de enero del 
figuración cambiante en el plano internacional — se incorporan nuevos países, que difuminan la distinción entre migración económica, política y ecológica (Ghosh, 1998: 147 s.) — y que exhiben una condición del inmigrante que también está en constante mutación, en eterna negociación de su identidad (Nair, 2006: 212).

b) Consecuentemente, el sistema económico capitalista ha impuesto, como paradigma de la breve duración de los hechos sociales, el ritmo frenético de las mercancías y de su consumo. Y si el tiempo de la mercancía se ha convertido en el modelo de las relaciones sociales (Sánchez Capdequí, 2004: 300), de la existencia social y de la vida humana, que han quedado convertidas en valores de cambio, en mercancías puestas en venta (Steingress, 2007, 189 s.; Roche, 2005: 37), no extrañe que también la emigración sea considerada una mercancía más (Nair, 2006: 169).

c) Este continuo y acelerado devenir de los hechos sociales, de la economía y de las migraciones dificulta enormemente la asimilación de la conciencia humana, cuyo tiempo biológico es más lento, por lo que no debe sorprendernos la perplejidad con la que los ciudadanos observan y acogen las migraciones, como tampoco debe extrañarnos la dificultad o la incapacidad de las instituciones para solventar con eficacia y sin riesgo los problemas sociales (Beck, 2006; Giddens, 2003: 33 s.), entre ellos, los migratorios.

Y, por lo que respecta a la manera de entender el espacio avasallado por el tiempo, las secuelas más trascendentes son las indicadas a continuación:

a) En la sociedad tardomoderna, postmoderna o de la información, la globalización «estrecha» los espacios y «desaleja la lejanía» (Safranski, 2004: 74-88) o relativiza la distancia y los límites espaciales (Aparicio, 2001: 12). Esto se observa muy bien en la evolución del capitalismo contemporáneo, puesto que éste se caracteriza por estar globalizado y externalizado y por ser extraterritorial, virtual, especulativo, conexionista, en red e invisible. Así es, la globalización ha producido el fortalecimiento de grandes empresas, a través de la formación de oligopolios en todos los mercados, cuyas mayores unidades se enfrentan entre sí a escala mundial y extienden su implantación y sus redes por todo el planeta. Al mismo tiempo, estas empresas se externalizan, es decir, que delegan parte de sus funciones o casi todas ellas en múltiples empresas subcontratadas o en franquicias situadas en el mismo territorio o en países lejanos, con lo cual se distancian de la ciudad y del mercado, de las asambleas y de los parlamen-

2006- en un período de diez años, el número de inmigrantes empadronados ha pasado a ser de 3.730.610 millones, lo que supone el 8,5\% del total de la población, que alcanza los 44.108.530 millones de personas. Así pues, en esta última década, se ha producido un aumento de extranjeros de más de 5 puntos porcentuales, lo cual ha situado a España al nivel de otros países europeos, como, por ejemplo, Francia (Algado, 2006). 
tos, de los gobiernos locales y de los nacionales, más allá del control de los ciudadanos, hacia la extraterritorialidad de las redes electrónicas. En estos años, se ha producido también la evolución desde la producción industrial a la cultural y desde el capitalismo de la propiedad hacia el virtual. En efecto, la economía se virtualiza ${ }^{8}$ cuando se acelera su abstracción en las últimas décadas del siglo XX — sobre todo a partir de 1973, con la globalización económica, con el incremento del volumen de los flujos financieros internacionales y con el aumento, a través de él, de la especulación en las finanzas mundiales- y se consuma la última fase de abstracción que llamamos virtual, en la que los mercados dejan sitio a las redes y el acceso sustituye cada vez más a la propiedad. Por otro lado, al haberse convertido la propiedad en capital, éste ya no se manifiesta en bienes específicos, sino como una suma abstracta que puede ser usada flexiblemente y cuyo valor se halla en su capacidad para obtener intereses o utilidades. Finalmente, la virtualización de la nueva economía se completa mediante los conceptos, las ideas, las imágenes, que son las que constituyen los auténticos artículos con valor y que han convertido al trabajo —al igual que los objetos materiales - en una fuerza menor ${ }^{9}$. Finalmente, el capitalismo se hace invisible, al igual que el conjunto de la sociedad, que es «compleja por el aspecto que nos ofrece (heterogeneidad, disenso, caos, desorden, diferencia, ambivalencia, fragmentación, dispersión), por la sensación que produce (intransparencia, incertidumbre, inseguridad), por lo que puede o no hacerse con ella (ingobernabilidad, inabarcabilidad)»(Innerarity, 2004: 14-5). También el nuevo capitalismo presenta un estado ideal de invisibilidad, en la medida en que no poseemos datos estadísticos ni de las empresas en red, ni del movimiento de las firmas multinacionales. Y ello sin olvidar que tampoco sabemos nada acerca de las subcontratas que hacen o de las franquicias que instituyen y que, además, ocultan al empleador para esquivar las constricciones del derecho laboral. Por tanto, representan un poder invisible en la medida en que es imposible conocer la tasa de concentración del poder económico. Los caracteres con los que acabo de definir a la economía, lógicamente influyen en los fenómenos migratorios que también muestran, sin perjuicio de adoptar caracteres más peculiares, una cierta relativización del espacio físico, una deslocalización, una invisibilidad y una virtualización o rostro imaginario, y ello debido a diversas circunstancias. En primer lugar, el avance de las nuevas tecnologías de la comunicación, de la información y de los transportes ha traído una relativización social del espacio físico, en la medida en que permite a los inmigrantes comunicarse y viajar y, con ello, relativizar las distancias entre su país de origen y el de destino (Viruela, 2007: 274) y efectuar varios retornos transitorios a su antiguo hogar (Cavalcanti, 2004). En segundo lugar, la deslocali-

8. La realidad virtual es un concepto que está interesando a la sociología, como puede apreciarse en la definición y en la bibliografía que sobre ella incluye el Diccionario de Sociología, de Octavio Uña Juárez y de Alfredo Hernández Sánchez, p. 1181-2.

9. Este cambio se ve muy bien en Nike, una empresa virtual que «vende conceptos» y que no posee ninguna fábrica ni máquinas, y también en las cada vez más numerosas franquicias. 
zación del trabajo ha afectado a las migraciones, pero de una manera ambivalente, puesto que, aunque las nuevas formas de división internacional del trabajo y las prácticas de deslocalización productiva han dado lugar a espacios de producción transnacionales, el cierre de las fronteras para la inmigración masiva y la aceptación de cupos selectivos de inmigrantes no han significado un verdadero mercado global del trabajo (Abad, 2003: 305 s.). Además, en los espacios transnacionales, la deslocalización de las migraciones adopta caracteres singulares, ya que la diversificación de los países de destino o la «deslocalización de los movimientos» es uno de los rasgos diferenciales de las migraciones actuales (González Rabanal, s. a.: 101 s.) y puesto que éstas no se reducen a un movimiento bipolar con contornos temporales precisos, sino que se crean en espacios globales que presentan múltiples dimensiones y que está formado por una serie de subespacios interrelacionados, sin límites y con frecuencia discontinuos, sobre todo en las ciudades fronterizas - de Estados Unidos de América y de México, por ejemplo- (Mendoza, 2004). Se podría decir, por tanto, que, en las migraciones, la deslocalización adopta formas espaciales todavía más imprecisas que en los sistemas productivos. En tercer lugar, se han generado espacios vacíos de significado, como los suburbios de los inmigrantes - los barrios de París o del Bronx en Nueva York, donde las clases medias no se atreven a entrar, se olvidan de que existen y los invisibilizan-, y no lugares, espacios de la circulación, de la distribución y de la comunicación en los que no se puede captar ni la identidad, ni la historia, ni la relación (Augé, 1996: 98). Finalmente, se han creado espacios imaginarios - como el Carnaval de Londres o la Feria de Abril de Barcelona- que manifiestan que los actores de estas fiestas, en origen inmigrantes, ya no se sienten ni del lugar del que proceden ni en el que se asientan, sino de ese espacio imaginario situado en ninguna parte concreta (Bauman, 2003: 211; Bauman, 2004: 145 s.). Además, igualmente han surgido espacios virtuales o decorados artificiales, como los parques de ocio o los centros comerciales (Baudrillard, 1984; Baudrillard, 1987), en los que parecen difuminarse las distancias o las diferencias entre los inmigrantes y los nacionales, pero que es un espacio de intercambio económico o de consumo, y no un auténtico espacio real social y físico, que era el que tradicionalmente había producido los intercambios sociales y la integración social, y que ha quedado, por tanto, achicado.

b) Todos estos cambios espaciales convergen en la reducción del espacio social (el ágora), al que también ayuda el triunfo de un individualismo descomprometido y la crisis de la ciudadanía y de diversas instituciones que representan el cemento social. Así es, por un lado, el capitalismo está marcado por el individualismo y la competitividad, ya que ya no está impulsado por el ascetismo racional - como ocurría en sus orígenes (Max Weber, La ética protestante y el espiritu del capitalismo)—, sino por la mera actividad personal y competitiva y ya que no está guiado por la responsabilidad con el otro, sino por la responsabilidad para uno mismo. Por tanto, se ha pasado de un mundo social empresarial dividido en grupos, al universo fragmentado y yuxtapuesto de des- 
tinos individuales y se ha desembocado en un divorcio entre el poder y la responsabilidad. Por otro lado, esto se corresponde con la crisis de la ciudadanía volcada en el interés común y público y con la de instituciones como la familia o el trabajo, que constituyen el cemento social (Bauman, 2003: $41 \mathrm{s.}$; Giddens, 2003: 65 s.). La pérdida del espacio social también se relaciona con la crisis del estado nación, con la consecuente aparición de espacios transnacionales - que traspasan las fronteras de los estados nación- e interculturales -espacios relacionales en los que interactúan los inmigrantes y la sociedad de acogida, intercambiando elementos económicos y culturales- (Solé, 2007: 159 s.). Estos nuevos espacios han instaurado redes que trascienden los territorios, pues vinculan dinámicamente las poblaciones de la sociedad emisora y las de la receptora (Gurak y otros, 1998: 76-7). Y ha estimulado, también, novedosas relaciones translocales entre las ciudades, que son los lugares clave de la actuación de los inmigrantes (Ramón, 2005: 61), especialmente en las ciudades globales - que poseen centros financieros, presencia de sedes de corporaciones internacionales, desarrollo de servicios de gestión empresarial y comercial, centros manufactureros, nudo de transportes, un tamaño considerable de población, mezcla multicultural de pobladores nacionales y extranjeros, concentración de elites artísticas y científicas y un numeroso turismo internacional - a las que abrumadoramente se dirigen los inmigrantes, al menos en el caso de Estados Unidos (Massey y otros, 1998: 226-7; García-Canclini, 2005: 167). Sin embargo, estas redes han conducido al inmigrante a «marcharse sin irse del todo", es decir, a partir físicamente pero no socialmente, lo cual ha dado lugar a la transnacionalidad o a la binacionalidad (Aparicio, 2001: 14 s.) y, a la inversa, ha llevado al inmigrante a quedarse sin quedarse del todo, a no participar activamente en la sociedad de acogida y a no votar en aquellas escasas sociedades en las que les está permitido el voto (la sueca, por ejemplo). Además, no hay que olvidar que estos espacios transnacionales traspasan las fronteras del espacio físico y social (Solé y otros, 2006: 21), que están todavía excluidos y que suprimen la vinculación de la sociedad a un lugar concreto (Beck, 2002: 49-52).

\section{Conclusiones}

1. Creemos que, en este artículo, siguiendo los objetivos propuestos, se han descrito los caracteres esenciales que definen las cuatro contradicciones más importantes — global-local, individuo-comunidad, identidad-diferencia y espacio-tiempo- de la sociedad global en la que se ven inmersas las migraciones. Creemos haber demostrado que las migraciones se producen en una sociedad globalizada llena de contradicciones y que estas contradicciones se nos han revelado como la causa y el efecto de los movimientos migratorios. También creemos haber evidenciado que han generado una serie de dilemas que hay que afrontar adecuadamente si queremos tener éxito en la gestión de las migraciones. Entre éstos destacan los siguientes: la reclamación en los asuntos migratorios de una ética global sin que todavía exista en ellos una política global; la intensifica- 
ción simultánea de polos antagónicos como la individualidad y lo colectivo, la identidad y la alteridad y la búsqueda por ser y la necesidad de relacionarse; que todo diálogo cultural se sustenta entre la jerarquización y el victimismo y que hay que huir de ambos; que los modelos migratorios impulsados por los estados parece que nos obligan o bien a vomitar o bien a devorar a los inmigrantes; que mientras que la globalización genera ciudadanos que se encuentran a sus anchas en el mundo - los empresarios-, también crea ciudadanos que no se sienten de ningún lugar — los inmigrantes-; y que los inmigrantes se marchan sin marcharse del todo de sus lugares de origen y que se quedan sin quedarse del todo en las sociedades de acogida y que, por tanto, se sitúan en un espacio-tiempo difuso, indeterminado y discontinuo, barrido por el impulso del devenir.

2. Hemos intentado clarificar hasta qué punto es posible solventar todas estas contradicciones y dilemas y los límites y obstáculos con los que nos encontramos, así como las posibilidades de éxito. Concretamente, sugerimos que todas estas contradicciones y dilemas obligan a la sociedad a responder a todas ellas, teniendo en cuenta a la vez los dos polos que conforman la paradoja o la contradicción (lo globaly lo local, el individuo y la comunidad, la identidady la diferencia y el espacio y el tiempo), aunque uno de ellos asuma el papel de preponderante, mientras que el otro lo haga de subordinado. En nuestra opinión, ello nos permitiría abordar los fenómenos migratorios con la complejidad que ellos requieren, ya que lo contrario sería caer en la simplificación (Berman, 1991). Lo que, en suma, estamos proponiendo es responder a los múltiples desafios que hoy presentan las migraciones en su integración en las sociedades de acogida de un modo simultáneo (Beck, 2006: 2), sin olvidar que no es ésta una tarea fácil de lograr, puesto que los tres tipos de integración social - funcional, moral y simbólica - en la sociedad moderna se articulan en diferentes tiempos, lo que impide la simultaneidad de los tres procesos de integración (Beriain, 1996: 122).

3. También hemos intentado llamar la atención sobre la importancia de la dimensión temporal en las migraciones y, específicamente, hemos querido resaltar que ya no podemos contemplarlas únicamente desde la perspectiva espacial, pues debemos incluir la dimensión temporal en los análisis, la interpretación y la articulación de politicas destinadas a las migraciones en la sociedad globali$z a d a$. En efecto, nos encontramos en un mundo desbocado y en devenir en el que prevalece el tiempo sobre el espacio, en el que los viajes incesantes y la rápida sucesión de acontecimientos y de noticias marcan nuestra vida cotidiana y en el que fluidamente transitan múltiples flujos informativos, financieros, económicos, políticos, religiosos, armamentísticos, culturales y humanos. Como nos reclamaba Hegel, estamos, por ello, obligados a pensar el cambio puro, es decir, a tomar conciencia de que ya no es la persecución de la estabilidad y del orden, sino el cambio el que domina las dinámicas sociales y culturales y de que lo social se da como temporalidad, es decir, que la sociedad no es únicamente reproducción y adaptación, sino también creación, pro- 
ducción de sí misma (Beriain, 1996: 59). Y es precisamente en este contexto en el que se desenvuelven las actuales migraciones que — como decíamos- son, al mismo tiempo, una causa y un efecto de tal contexto, o sea, el fruto de esa dinámica de cambio y también impulsoras de hondas variaciones en las estructuras sociales y culturales. Debemos, pues, pensar que las migraciones se producen en el espacio o, mejor dicho, en espacios en crisis, con una profunda y acelerada transformación. Y si a ello se le añade que el espacio está dominado por un tiempo caótico, fragmentario, azaroso y convertido en mercancía, entenderemos entonces que esta construcción temporal nos complique enormemente y que no nos permita resolver adecuadamente los retos de los que se ha venido hablando en este artículo, es decir, que no tenemos tiempo, que no contamos con el tiempo suficiente, para conciliar la globalización y la localización, la individualización y lo colectivo, la identidad y la diferencia y, en definitiva, el espacio y el tiempo. Al parecer éste es el rasgo común de las teorías que las ciencias sociales desarrollan para captar la realidad migratoria, ya que no logran una amplia aceptación, porque los fenómenos que explican evolucionan más allá de su comprensión (Portes y otros, 1998: 43). Ahora bien, como sociólogos, debemos resaltar tanto los obstáculos con los que nos encontramos como las posibilidades que se nos presentan, es decir, debemos desvelar de nuevo la contradicción en la que se desarrollan los fenómenos sociales. $\mathrm{Y}$, en este sentido, si es verdad que no tenemos tiempo para resolver adecuadamente los embates de las migraciones, también lo es que no podemos convertir al tiempo en su enemigo, sino que, al revés, éste —al igual que ocurre con la identidad-debe ser considerado su condición.

4. Nos hallamos también en un mundo en el que «los mitos de la ruta» se contrarrestan con «los mitos de la frontera» (Pérez Herranz, 2006: 32), esto es, en un planeta de compartimentos y de fluidos que aspira a ser global, pero que se resiste a perder la identidad de lo local; un mundo en el que los problemas planetarios económicos, ecológicos, demográficos, sanitarios, alimenticios y migratorios y en el que los conflictos armados étnicos, religiosos y culturales generales no pueden ser gestionados desde lo local; un mundo, finalmente, en el que los asuntos más cercanos de los ciudadanos ya no pueden ser abordados con éxito por los entes estatales. Se explica, así, que la identidad cultural se haya convertido en una necesidad y también en un problema; que «la humanidad se decline en plural» (Finkielkraut, 2000: 14-68), esto es, que la cultura aspire a la unidad y se manifieste en la diversidad, que sea una «unidad de diferencias» en la que comparecen la diferenciación y la globalización (Beriain, 1996: 155), y que quede planteada la profunda cuestión ética de considerar a los inmigrantes como extranjeros en un mundo que, teóricamente, debería derribar todas las fronteras. 


\section{Bibliografía}

Abad Márquez, Luis V. (2002). "Contradicciones de la globalización: Migraciones y convivencia interétnica tras el 11 de septiembre». Migraciones, núm. 11.

- (2003). "Economía en red y políticas migratorias: ¿hacia un mercado global del trabajo?». Migraciones, núm. 14.

- (2005). "Inmigración y cooperación al desarrollo». En: ABAD, Luis V. y otros. Codesarrollo: migraciones y desarrollo mundial. Madrid: CYDEAL.

Algado Ferrer, M. (2006). «Impacto demográfico de la inmigración en España». En: RodrígueZ, J. (ed.). Sociología para el futuro. Barcelona: Icaria.

APARICIO, Rosa (1981). Cultura y sociología. Madrid: Narcea.

- (2001). Convivir como tarea: Nuevas demandas de la sociología de las migraciones. Madrid: Universidad Pontificia Comillas.

ARANGO, Joaquín (2003). «Inmigración y diversidad humana. Una nueva era en las migraciones internacionales». Revista de Occidente, núm. 268.

Aubarell, Gemma; Aragall, Xavier (2005). «El papel de las administraciones públicas». En: ABAD, Luis V. y otros. Codesarrollo: migraciones y desarrollo mundial. Madrid: CYDEAL.

Augé, Marc (1996). El sentido de los otros. Actualidad de la antropología. Barcelona: Paidós.

Baudelaire, Charles (2004). El pintor de la vida moderna. Murcia: Colegio Oficial de Aparejadores y Arquitectos Técnicos. Consejería de Educación y Cultura. Fundación Cajamurcia.

BAUDRILlard, Jean (1978). A la sombra de las mayorías silenciosas. Kairós: Barcelona.

- (1984). Cultura y simulacro. Barcelona: Kairós.

- (1987). América. Barcelona: Anagrama.

BAUMAN, Zygmunt (2002). La cultura como praxis. Barcelona: Paidós.

- (2003). Modernidad líquida. Buenos Aires: FCE.

- (2004). La sociedad sitiada. Buenos Aires: FCE.

- (2006). Vida líquida. Barcelona: Paidós.

BAUMER, Franklin (1985). El pensamiento europeo moderno: Continuidad y cambio en las ideas, 1600-1959. México: FCE.

BECK, Ulrich (2002). ¿Qué es la globalización? Falacias del globalismo, respuestas a la globalización. Barcelona: Paidós.

- (2005). La mirada cosmopolita o la guerra es la paz. Barcelona: Paidós.

- (2006). La sociedad del riesgo global. Madrid: Siglo XXI.

BELL, Daniel (1992). Las contradicciones culturales del capitalismo. Madrid: Alianza. Benjamin, Walter (1973). Discursos interrumpidos. Madrid: Taurus.

BERIAIN, Josetxo (1996). La integración en las sociedades modernas. Barcelona: Anthropos.

BERMAN, Marshall (1991). Todo lo sólido se desvanece en el aire. La experiencia de la modernidad. Madrid: Siglo XXI.

Boltanski, Luc; Chiapello, Éve (2002). El nuevo espiritu del capitalismo. Madrid: Akal.

Bronowski, J. (1978). El sentido común de la ciencia. Barcelona: Península.

CASTORIADIS, C. (1979). Capitalisme moderne et révolution. Vol. 2. París: Union Générale d'Édition.

CAVALCANTI, Leonardo (2004). "La influencia de las nuevas tecnologías en el retorno de los inmigrantes contemporáneos». Scripta Nova. Revista electrónica de Geografía y Ciencias Sociales, vol. vIII, núm. 170 (38). 
Coppens, Carolina (2002). Las ruinas circulares y la poética del margen: Un ensayo sobre identidad, globalización y arte. Valencia: Institució Alfons El Magnànim. Diputació de Valencia.

Dante Alighieri (1995). Divina Comedia. Madrid: Alianza Editorial.

DARWIN, Charles (1985). El origen de las especies. Barcelona: Planeta-Agostini.

- (1986). Teoría de la evolución. Barcelona: Planeta-Agostini.

DeBorD, Guy (2003). La sociedad del espectáculo. Valencia: Pre-Textos.

DEWEY, John (2003). Viejo y nuevo individualismo. Barcelona: Paidós.

Eliade, Mircea (1952). El Mito del Eterno Retorno. Buenos Aires: Emecé Editores.

FINKIELKRAUT, Alain (2000). La derrota del pensamiento. Barcelona: Anagrama.

FREUD, Sigmund (1995). El malestar en la cultura. Madrid: Alianza.

Fullat, Octavi (2002). El siglo postmoderno (1900-2001). Barcelona: Crítica.

GALTUNG, Johan (1995). Investigaciones teóricas: sociedad y cultura contemporáneas.

Madrid: Tecnos.

GARCÍA-CANCLINI, Néstor (2001). Culturas hibridas. Estrategias para entrar y salir de la modernidad. Buenos Aires: Paidós.

- (2004). Diferentes, desiguales y desconectados. Mapas de la interculturalidad. Barcelona: GEDISA.

- (2005). La globalización imaginada. Buenos Aires: Paidós.

GHOSH, Bimal (1998). «La migración económica y los países emisores». En: MALGESINI, Graciela. Cruzando fronteras. Migraciones en el sistema mundial. Madrid: IcariaFundación Hogar del Empleado.

GIDDENS, Anthony (2003). Un mundo desbocado. Los efectos de la globalización en nuestras vidas. Madrid: Taurus.

GonZÁleZ GARCÍA, José M. (1992). Las huellas de Fausto. La herencia de Goethe en la sociología de Max Weber. Madrid: Tecnos.

GONZÁleZ RABANAL, M. de la Concepción (s. a.). «El control de las migraciones y la globalización de las economías ¿Fenómenos comparables?». Revista del Ministerio de Trabajo y Asuntos Sociales, núm. 51.

GURAK, Douglas; CACES, Fe (1998). «Redes migratorias y formación de sistemas de migración». En: MALGESINI, Graciela. Cruzando fronteras. Migraciones en el sistema mundial. Madrid: Icaria-Fundación Hogar del Empleado.

HaRveY, D. (1998). La condición de la postmodernidad. Buenos Aires.

HeGEL, G. W. F. (2000). Fenomenología del espíritu. Madrid: FCE.

Heilbroner R.; Milberg, W. (1999). La evolución de la sociedad económica. México: Prentice May.

Herkovits, Melville J. (1987). El hombre y sus obras. México: FCE.

IGLESIAS, Carmen (1999). Razón y sentimiento en el siglo XVIII. Madrid: Real Academia de la Historia.

INNERARITY, Daniel (2004). La sociedad invisible. Madrid: Espasa.

IZQUiERdo Escribano, Antonio; FERnÁNdEZ SuÁreZ, Belén (2007). "La inmigración en la España 2005-2006. Entre la normalización y el flujo de cayucos». En: NAVARro, Vicent. La situación social en España. Volumen II. Madrid: Fundación Largo Caballero.

JaY, Peter y STEWART, Michael (2000). Apocalipsis 2000. ¿Decadencia económica y suicidio de la democracia? 1989-2000. Madrid: EDAF.

Jameson, F. (1998). Teoría de la postmodernidad. Madrid: Trotta.

JUÁREZ, M. (dir.) (1995). V informe sociológico sobre la situación social en España, «Sociedad para todos en el año 2000». Madrid: Fundación FOESSA. 
KANT, Immanuel (2003). Crítica de la razón pura. Madrid: Alfaguara.

LACOMBA, Joan (2005). «Marruecos: realidades de las migraciones y posibilidades del codesarrollo". En: ABAD, Luis V. y otros. Codesarrollo: migraciones y desarrollo mundial. Madrid: CYDEAL.

LÉVI-STrauss, Claude (1988). Tristes trópicos. Barcelona: Paidós.

LONGAIR, Malcolm S. (1998). La evolución de nuestro universo. Madrid: Cambridge University Pres.

López SALA, Ana María (2005). Inmigrantes y estados: La respuesta política ante la cuestión migratoria. Barcelona: Anthropos.

MaAlouf, Amin (2004). Identidades asesinas. Madrid: Alianza.

MALGESINI, Graciela (1998). «Introducción». En: MALGESINI, Graciela. Cruzando fronteras. Migraciones en el sistema mundial. Madrid: Icaria-Fundación Hogar del Empleado.

MARDONES, José María (2001). «El multiculturalismo como factor de modernidad social». En: COlOM, Francisco (ed.). El espejo, el mosaico y el crisol: Modelos politicos para el multiculturalismo. Barcelona: Anthropos.

MarX, Karl (1985). Trabajo asalariado y capital. Barcelona: Planeta-Agostini.

- (1987). El manifiesto comunista. Madrid: Textos Universitarios-Ediciones Endimión.

MASSEY, Douglas; ARANGO, Joaquín y otros (1998). «Una evaluación de la teoría de la migración internacional: el caso de América del Norte». En: MALGESINI, Graciela. Cruzando fronteras: Migraciones en el sistema mundial. Madrid: Icaria-Fundación Hogar del Empleado.

Mendoza PÉREZ, Cristóbal (2004). «Circuitos y espacios transnacionales en la migración entre México y Estados Unidos: Aportes de una encuesta de flujos». Migraciones Internacionales, vol. 2, núm. 3, enero-junio.

Mills, C. Wright (1999). La imaginación sociológica. Madrid: FCE.

Morán EsCOBEDO, Juan G. (2001). «Al norte del liberalismo: el contexto canadiense de un debate filosófico». En: COLOM, Francisco (ed.). El espejo, el mosaico y el crisol. Modelos politicos para el multiculturalismo. Barcelona: Anthropos.

MORÉ, Iñigo (2005). "Las remesas de los inmigrantes y su contribución al desarrollo». En: ABAD, Luis V. y otros. Codesarrollo: migraciones y desarrollo mundial. Madrid: CYDEAL.

Moreno, Isidoro (2005). «Globalización y cultura». En: RochE Cárcel, Juan A. y Oliver Narbona, Manuel. Cultura y globalización: Entre el conflicto y el diálogo. Alicante: Universidad.

MORENO, Luisa (2005). «Integración y codesarrollo: ¿realidad o quimera?». En: ABAD, Luis V. y otros. Codesarrollo: migraciones y desarrollo mundial. Madrid: CYDEAL.

Naciones Unidas (2006a). Trends in total Migrant Stock. The 2005 Revision.

NaCiOnes Unidas (2006b). World Economic and Social Survey 2006.

NaCiOnes UnidAs (2006c). Migración internacional y desarrollo. Asamblea General. Informe del Secretario General, 18 de mayo.

NAIR, Sami y LuCAS, Javier de (1999). Inmigrantes. El desplazamiento en el mundo. Madrid: Ministerio de Trabajo y Asuntos Sociales. Secretaría General de Asuntos Sociales. Instituto de Migraciones y Servicios Sociales.

NAIR, Sami (2006). Y vendrán las migraciones en tiempos hostiles. Barcelona: Bronce.

Pérez Herranz, Miguel y Santacreu Soler, José Miguel (2006). Las rutas de la humanidad: Fenomenología de las migraciones. Valencia: Edicions La Xara.

PORTES, Alejandro y BÔRÔTCZ, József (1998). «Migración contemporánea: Perspectivas teóricas sobre sus determinantes y sus modalidades de incorporación». En: 
MALGeSINI, Graciela. Cruzando fronteras. Migraciones en el sistema mundial. Madrid: Icaria. Fundación Hogar del Empleado.

RAMÓn CHORneT, Consuelo (2005). «La política de codesarrollo en la Unión Europea: ¿hacia una inflexión significativa?». En: ABAD, Luis V. y otros. Codesarrollo: migraciones y desarrollo mundial. Madrid: CYDEAL.

RAMOS TORRE, Ramón (1999). "Red, identidad, espacio y tiempo». Revista Española de Investigaciones Sociológicas, núm. 86.

RifKIN, J. (2000). La era del acceso: La revolución de la nueva economía, Barcelona: Paidós.

ROBERTSON, Roland (1992). Globalization: Social theory and global culture. Londres: Sage.

RoCHE CÁRCEL, Juan A. (2004). "El capitalismo evanescente». En: Reflexiones sociológicas. Homenaje a José Castillo Castillo. Madrid: CIS.

- (2005). «La construcción cultural de la realidad social en la Modernidad». Papers. Revista de Sociología, núm. 77.

RODRÍGUEZ, Ramón (2007). «El tiempo y las incertidumbres de la identidad». En: Roche CÁrCel, Juan A. Espacios y tiempos inciertos de la cultura. Barcelona: Anthropos.

RuSSELL, Bertrand (1984). ABC de la relatividad. Barcelona: Ariel.

SAFRANSKI, Rüdiger (2004). ¿Cuánta globalización podemos soportar? Barcelona: Tusquets.

SÁNCHEZ CAPDEQUí, Celso (2004). Las máscaras del dinero: El simbolismo social de la riqueza. Barcelona: Anthropos.

SARTORI, Giovanni (2003). La sociedad multiétnica. Pluralismo, multiculturalismo, extranjeros e islámicos. Madrid: Taurus.

SENNET, Richard (2000). La corrosión del carácter. Las consecuencias personales del trabajo en el nuevo capitalismo. Barcelona: Anagrama.

- (2006). La cultura del nuevo capitalismo. Barcelona: Anagrama

SERRA YOLDI, I. (2000). «La inmigración extranjera en el Mediterráneo: balance y actitudes». En: NiNYOLES, R. (ed.) La societat valenciana: estructura social $i$ institucional. Alzira: Bromera.

- (2001) «Inmigración femenina, diversidad cultural y trabajo». En: DuRÁN, M. A.; SERrA, I. y TORADA, R. Mujer y trabajo: Problemática actual. Valencia: Germania. Simmel, Georg (1977). Filosofía del dinero. Madrid: Instituto de Estudios Políticos. - (1986). El individuo y la libertad. Barcelona: Península.

SMiTH, Adam (2007). La riqueza de las naciones. Madrid: Alianza Editorial.

SOLÉ, Carlota y CACHÓN, Lorenzo (2006). «Globalización e inmigración: los debates actuales». REIS, núm. 116, octubre-diciembre.

SOLÉ, Carlota (2007). «Inmigración y espacios transnacionales e interculturales». En: Roche CÁrCel, Juan A. Espacios y tiempos inciertos de la cultura. Barcelona: Anthropos.

STEINGRESS, Gerhard (2007). «El tiempo como fuente de valor e incertidumbre. Sobre la economía política del tiempo explotado en las sociedades avanzadas». En: RoCHE CÁRCEL, Juan A. Espacios y tiempos inciertos de la cultura. Barcelona: Anthropos. STEINER, George (2001). Gramáticas de la creación. Madrid: Siruela.

STIGLITZ, Joseph (2003). El malestar en la globalización. Madrid: Taurus.

TAPINOS, George Photios (2000). «Mundialización, integración regional, migraciones internacionales». Revista Internacional de Ciencias Sociales, núm. 165, septiembre.

TARDif, Jean (2004). "Identidades culturales y desafíos geoculturales». Pensar Iberoamérica. Revista de Cultura, núm. 6. Organización de Estados Iberoamericanos. 
THIEBAUT, Carlos (1996). «La mal llamada postmodernidad (o la contradanzas de lo moderno)». En: BOZAL, Valeriano. Historia de las ideas estéticas y de las teorías artísticas contemporáneas. Vol. II. Madrid: Visor.

UGUR, Mehmet (1998). «Libertad de circulación versus exclusión: una reinterpretación de la división "propio"-"extraño" en la Unión Europea». En: MALGESINI, Graciela. Cruzando fronteras: Migraciones en el sistema mundial. Madrid: Icaria. Fundación Hogar del Empleado.

Uña Juárez, Octavio y Hernández Sánchez, Alfredo (2004). Diccionario de Sociología. Madrid: ESIC Editorial.

VelasCo ARroyo, Juan Carlos (2001). «Liberalismo y derechos de las minorías: una relación conflictiva». En: Colom, Francisco (ed.). El espejo, el mosaico y el crisol. Modelos políticos para el multiculturalismo. Barcelona: Anthropos.

VirUela MARTíneZ, Rafael (2007). «Migración y nuevas tecnologías de la información y la comunicación: inmigrantes rumanos en España». Revista Migraciones, núm. 21.

WeBER, Alfred (1969). Historia de la cultura. México: FCE. 